\title{
RELIGION, TRADITION, AND THE DYNAMICS OF ISLAMIZATION IN SOUTH SULAWESI ${ }^{1}$
}

\author{
Christian Pelras
}

The Bugis, Makassar, and Mandar peoples of South Sulawesi are known as having embraced Islam between 1605-when, according to local sources, the dat $u^{\prime}$ of Luwu' La Patiware' Daéng Parabung, converted with all his family, adopting the Muslim name of Sultan Muhammad Waliu'l-Mudharuddin-and 1611, when the last pagan prince of Boné submitted to the Goanese troops. ${ }^{2}$

Ever since, Islam has been considered as a prime element of the cultures of these peoples, whom many in Indonesia take as being among the most "fanatik" Muslims in the Archipelago. And indeed, it cannot be by chance that South Sulawesi, together with Aceh and West Java, was during the fifteen years which followed the recognition of Indonesian independence, harried by a merciless civil war waged in the name of the Darul Islam.

However, an anthropologist staying for some time in the field cannot help being struck by the long-lived survival there of pre-Islamic elements-which would be called tahyul by many orthodox, especially non-Bugis, Muslims-such as: taking as truth the episodes of La Galigo which feature several godly couples living in heaven and in the underworld and populating the earth by sending their offspring and the latter's servants there as respective ancestors to the nobility and commoners; ${ }^{3}$ venerating as regalia descended from heaven with the first rulers material objects such as spades, banners, ploughs, etc.; the existence in a few places of a class of transvestite pagan priests, called bissu, in charge of the cult of these regalia and of princely ceremonials; 4 the perpetuation of lively popular beliefs about place

1 This article is based on a lecture given in October 1983 to the Indonesia Study Group, Australian National University, Canberra. I am grateful to the Department of History, Faculty of Arts, and Department of Southeast Asian Studies, Faculty of Asian Studies at the ANU for having kindly extended to me an invitation to visit there, for three months in the fall of 1983. The English text, which first appeared in Archipel 29 (1985): 107-35, has been revised by Josiane Massard and Stephen Headey to whom I express my best thanks.

2 see J. Noorduyn, "De islamisering van Makassar," BKI 62 (1956): 247-66, and Mattulada, Islam di Sulawesi Selatan (Jakarta: LEKNAS/LIPI, 1976).

${ }^{3}$ For a short summary of La Galigo, see my article "Introduction à la littérature bugis," Archipel 10 (1975): $239-67$.

4 The most recent description of the bissu priests and their ritual is by Gilbert Hamonic, "Les fausses femmes' du pays bugis (Célèbes-Sud)," Objets et Mondes, 17, 1 (1977): 39-46 and "Mallawolo, chants bugis pour la sacralisation des anciens princes de Célèbes-Sud," Archipel 19 (1980): 43-79. 
spirits, guardian spirits, or evil spirits, to which offerings are brought; and a whole set of rituals including "rites de passage" (with aristocratic and popular variants) and house building, boat building, agricultural, and ancestor worship rituals. ${ }^{5}$

When confronting such contradictory evidence, one can raise several questions. One, of course, is to what extent do these apparently contradictory elements really coexist? And, if so, how is this possible in a society which claims to be genuinely Islamic, and what led to such a situation? Unavoidably, one will have to question the appropriateness of using here categories similar to those of santri/abangan/priyayi coined by Clifford Geertz for Java. 6

But, to my eyes the main question should concern the validity for South Sulawesi of the concept of "Islamization" as it is commonly used. Indeed it seems to me that "Islamization" is too often taken as pointing to an event, or a series of events, all precisely dated, whereas one should understand it as a process, and a long one for that matter, including two important phases: first, the coming of Islam and its final official acceptance; and then, the long struggle, lasting often until now, for its complete implementation. In both phases, the same dynamics, made up of the opposition of constant contradictory forces, appear to be at work. And one has to identify these forces in order to understand better the vicissitudes of Islamization in that broader sense in South Sulawesi.

\section{The Coming of Islam in South Sulawesi}

As the quasi-official story runs, Islam was brought to South Sulawesi at the beginning of the 17th century by three muballigh, collectively known as Dato' Tallua in Makassarese or Dato' Tellué in Buginese (the Three Dato') and individually, after their burial places, as respectively Dato' ri Bandang (his name was Abdul Makmur, and nickname khatib Tunggal), Dato' ri Pattimang (Sulaiman, alias khatib Sulung), and Dato' ri Tiro (Abdul Jawad, alias $k$ hatib Bungsu). They are said to have come from Kota Tengah in the Minangkabau country of Sumatra, and the latter two must have been brothers.

According to local sources, they went first to Luwu', still the most prestigious kingdom in South Sulawesi and converted the Datu (ruler) La Patiware' Daéng Parabung, who on the 15 or 16 of Ramadhan 1013 AH (February 4 or 5,1605 ) uttered the syahadat and took the name of Sultan Muhammad. They then proceeded to the twin state of Ooa and Tallo' (known as Makassar by outsiders), which was at that time the most powerful in the peninsula. Due to their teaching, the "Old Prince" (Karaéng Matoaya) I Mallingkaang Daéng Manyonri' Karaéng Katangka, the ruler of Tallo' and prime minister of Goa, adhered to the new faith with several members of his family, and uttered the syahadat on Friday's eve, 9 of Jumadilawal (September 22, 1605), taking the new name of Sultan Abdullah. Then, under his influence, the young ruler of Goa, I Manga'rangi Daéng Manrabbia, who was his nephew and pupil, became a Muslim too. On Friday, 19 of Rajab 1016 (November 9, 1607), the first solemn public prayer was held at the newly built Tallo' mosque: the Makassar kingdom had officially become a Muslim state.

The next step of Sultan Abdullah was to invite the other South Sulawesi rulers to convert to Islam. On their refusal, he decided to resort to weapons and launched several successive campaigns known in Buginese as musu' selleng "the Islamic wars." In 1608, Sawitto, Bacukiki, Suppa', and Mandar on the west coast, Akkotengeng and Sakkoli' on the east coast submitted and were Islamized. In 1609, came the turn of Sidénréng and Soppéng; in

\footnotetext{
${ }^{5}$ See my article "Les éléments du rituel populaire bugis," Ethnologica Helvetica, 10 (in press).

${ }^{6}$ Clifford Geertz, The Religion of Java (Chicago-London: The University of Chicago Press, 1960).
} 
1610, that of Wajo'; in 1611, with the final submission of Boné, all of South Sulawesi except for the Toraja mountains had accepted Islam. ${ }^{7}$

That story, combined with numerous local legends about the first arrival of the three Dato' and their marvellous deeds, ${ }^{8}$ conveys the impression that the passage of the major part of South Sulawesi to Islam was very rapid indeed.

All those events are well known and the dates, about which previous authors had been disputing for a long time, have been established, in my opinion beyond any doubt, by J. Noorduyn. However, if, as he himself pointed out, one has to distinguish between conversion to Islam and the coming of Islam, it appears that that coming is not very well documented, except for a few data which one finds repeated everywhere: the bestowing, under the Goa ruler Tunipalangga (about 1546-1565) of a number of privileges to the Muslim community of Makassar, made up of traders from Champa, Patani, Pahang, Johor, and Minangkabau; the building of a mosque for that community in the Mangallékanna suburb of Makassar by his successor Tunijallo' (about 1565-15909); or the visit paid to the latter around 1580 by Baabullah, Sultan of Ternate, who, according to a Moluccan tradition collected by Valentijn in his book Oost Indië Oud en Nieuw, was said to have brought him to Islam. ${ }^{10}$

It may be that the "golden legend" of the Three Dato', like that of the Nine Wali in Java, has shrouded many other events which would show that Islamization in South Sulawesi began with a long process of familiarization. However, I am convinced that a better scrutiny of written sources, including sources from other Indonesian areas, together with systematic collecting of local traditions, would lead us to a much more complicated picture than the one to be found in present textbooks, and beyond that, would help us understand which forces were at work in the Islamization of the area.

One point, already underlined by the three events reported about the reigns of Tunipalangga and Tunijallo' has to be made clear: the Makassar people, probably also the Bugis people, and their rulers, had known Islam for a long time when they decided to become Muslim themselves; when the first Portuguese known to have visited South Sulawesi arrived in 1542 in Siang (formerly a powerful state, and at that time still an important trading harbor), they were even told that the Muslim Malay traders from Patani, Pahang, and Ujung Tanah living there had been established in the country for about sixty years, i.e., since about $1480 .{ }^{11}$ It is unlikely that Siang was the only harbor in South Sulawesi where Malay communities existed; there must have been others, which might be traced, inter alia through Malay sources.

For instance, one Sayyid Husein Jamadul Qubra is said in Kelantanese sources to have left Kelantan in 1448, and after a stay of four years in Java, to have gone to Wajo' where he

\footnotetext{
7 Noorduyn, "De islamisering van Makassar."

${ }^{8}$ Mattulada, Islam di Sulawesi Selatan, pp. 9-11. See also in this volume the article by H. Chambert-Loir on "Dato' ri Bandang."

${ }^{9}$ G.J. Wolhoff and Abdurrahim, "Sedjarah Goa," Bingkisan Sulawesi Selatan dan Tenggara, A, 1 (Makassar, n.d. [1960?]), pp. 26-28.

${ }^{10}$ F. Valentijn, Oud en Nieuw Oost-Indiën, 8 vols. (Dordrecht, 1724-1726; new annotated edition by S. Keijzer, The Hague, 1858): 4, 140.

${ }^{11}$ H. Jacobs, "The First Locally Demonstrable Christianity in Celebes, 1544," Studia [Lisbon] 17 (1966): 295.
} 
died in $1453 .{ }^{12}$ The dates may be not completely reliable since at that time Wajo' was still an unimportant place, known under the name of Cinnottabi'. But at least, these are external data, which could he cross-checked with others, pointing to relations between the Muslim Malay Peninsula and South Celebes already in the middle of the 15th century. One should look for others in Malay sources in the Peninsula, Brunei, or other Bornean sultanates, and in Sumatra, as well as in Javanese and Ternatese sources; in short, in all places in the Archipelago where Islam was progressing in the second half of the 15th century.

The role of Muslim traders acting as muballigh is well known everywhere; we know also that Muslim traders were established at that time in South Sulawesi; no wonder if they acted in a similar way there too. The role of that region in the interinsular trade was then not yet very important, as compared to other places in the Archipelago, ${ }^{13}$ but links existed with the most important trading centers in the area, including Ternate, north Javanese harbors, Banten, and Malaka. ${ }^{14}$ People there, and especially the sailors or local traders in contact with foreigners from those centers, must have been well aware of the progression of Islam in those parts; whereas the rulers in the numerous South Sulawesi kingdoms then struggling among themselves in the wake of the decline of the formerly powerful Luwu', could not hear without interest the news about conversion to Islam in neighboring North and Southeast Sulawesi kingdoms such as Gorontalo (1525) and Buton (1542). ${ }^{15}$

By the middle of the 16th century, South Sulawesi was one of the very few important places in the interinsular trading network on which Islam had not yet taken hold. That kind of anomaly must have been keenly felt, by local Muslim settlers as well as by other Muslim communities in the Archipelago. As expected, it provoked projects or attempts, some of which can be cited here, whereas more might be found if systematic research were done on that question. For instance:

In 1548, when the Portuguese Manoel Pinto, on his way back to Malaka from South Sulawesi, called on the "main king of Java," probably the Sultan of Demak, the latter told him that he was contemplating the launching of a military expedition against that land in order to Islamize it. ${ }^{16}$ That Sultan was killed in 1549 , and this may be the reason why such an expedition never occurred. ${ }^{17}$

Probably around 1560, according to Acehnese sources, one Raja Abdul Jalil Putra, a son of Sultan Alauddin Riayat Syah al-Qahar of Johor (who reigned from 1537 to 1568) and a brother of Sultan Ali Riayat Syah of Aceh (who reigned from 1568 to 1575), is said to have

12 Wan Muhammad Saghir, Sejarah Ulama-ulama Islam Nusantara (Kuala Lumpur: Kementerian Kebudayaan, Belia dan Sultan, forthcoming); cited by Abdul Rahman al-Ahmadi, "Sejarah hubungan Kelantan/Patani dengan Sulawesi Selatan." Paper for the Diplome d'Etudes Approfondies, Ecole des Hautes Etudes en Sciences Sociales (Paris, 1981), pp. 4-5.

${ }^{13} \mathrm{Ch}$. Pelras, "Célèbes-Sud avant l'islam, selon les premiers témoignages étrangers," Archipel 21 (1981): 163.

14 Tomé Pires, The "Suma Oriental" of Tomé Pires: An Account of the East, from the Red Sea to Japan, written in Malacca in 1512-1515, translated and edited by Armando Cortesâo (London: Hakluyt Society, 1944), pp. 326-27.

${ }^{15}$ S. R. Nur, "Beberapa aspek hukum adat tatanegara kerajaan Gorontalo pada masa pemerintahan Eato," (Dissertation, Universiti Hasanuddin, Ujung Pandang, 1979), p. 20 and Zahari, Sejarah dan adat Fiy Darul Butuni (Buton), vol. 1 (Jakarta, 1977), pp. 44 ff.

${ }^{16}$ Letter written by Manoel Pinto on the 7th of December 1548 to the Bishop of Goa in India, in Joseph Wicki, Documenta Indica: Monumenta Societatis Jesu a patribus eus-dem Societatis edita, vol. 11 (1550-1553) (Rome, 1950), pp. 422-23.

${ }^{17}$ Th. G. Th. Pigeaud and H. J. de Graaf, Islamic States in Java, 1500-1700, Verhandelingen KITLV (70), The Hague, 1976, p. 9. 
traveled to South Sulawesi in company with a muballigh of Pidië (in the north of Sumatra). Those sources say that, due to their influence, a ruler of Boné was converted. ${ }^{18}$

Nothing of that kind is to be read in Bugis chronicles, but it might mean, either that the ruler was just made a sympathizer, or that the news concerned, not the ruler of Boné (the Arung Mponé), but just a ruler in Bone, i.e. the lord of a vassal lordship. Anyway, that raja Abdul Jalil married a Bugis wife, and one of their sons, Daéng Mansur, known in Aceh as Teungku di Bugéh, went back to Surnatra where he married the daughter of an ulama in Ribéë. Their daughter, Sitti Sani, was to become the wife of the great Sultan Iskandar Muda (1601-1636) and the ancestress of the so-called "Bugis dynasty" in Aceh.

In this connection, it may be interesting to note that in Bira, at the southeastern-most point of the peninsula, opposite Selayar island, people say that Islam was brought to the area by an Acehnese called Syeikh Ahmad who had come first to Sinjai, where he married the daughter of the Lord of Lamatti. From that union, two sons were born-one went to Boné; the other, known as Syeikh Abdul Rahman, came to Bira where he made many converts. His two sons, Abdul Jalil and Abdullah, carried his work on, but the most venerated figures there are Abdul Jalil's son, Abdul Basir Daéng Billa', and Abdullah's son, Abdul Haris alias Pua' Janggo'. Until now in Bira two groups claim to follow their respective teachings. The followers of Abdul Basir are said to have been more concerned with the "external" (lahir) aspects of religion, whereas those of Pua' Janggo' were mostly centered on "interiority" (batin) or mysticism. According to local tradition, the latter entered into competition with Dato' Tiro (Tiro is only a few kilometers from there), and of course Pua' Janggo' won. If the story is not anachronistic, and if the two masters were contemporaries indeed, it would mean that Pua' Janggo's great-grandfather might have come to South Sulawesi at about the middle of the 16 th century..$^{19}$

In 1564, according to Malay sources, one Syeikh Abdul Wahid bin Syarif Sulaiman alPatani is said to have traveled from Patani to Buton, which had become Muslim not long before, to instruct poeple in the new faith. ${ }^{20} \mathrm{He}$ may have called at Makassar, which had had a long-standing relationship with that neighboring kingdom.

Around 1575, according to the Kutei chronicle, one of the future Dato' Tallua, Dato' ri Bandang, known there as Tuan di Bandang, had been in South Sulawesi with a companion called Tuan di Parangan, in order to propagate Islam. Their attempt having been unsuccessful, they came to Kutei, which they succeeded in bringing to their faith. ${ }^{21}$

In 1580, according to Valentijn, who based himself on Moluccan sources, Baabullah, Sultan of Ternate, whose influence extended as far as North, East, and Southeast Sulawesi, came to Makassar. His aim must have been to negotiate new frontiers between Goanese and Ternatese spheres of influence, but those sources say that he succeeded in converting the ruler of Goa, then I Manggorai Daéng Mamméta Karaéng Bontolangkasa', known after death as Tunijallo' (about 1565-1590).22 No such conversion is recorded, however, in Makassar chronicles, which just say Baabullah recognized Goa influence on Selayar island.

18 H.M. Zainuddin, Tarich Atjeh.

19 Interview with M. Andi' Amiruddin Said Patunru', village head in 1984, and a descendant of the family of the Karaéng (local lords).

20 Abdul Rahman al-Ahmadi,"Sejarah hubungan Kelantan/Patani," p. 4.

21 C.A. Mees, De kroniek van Koetei ( Santpoort, 1935), pp. 100 and 240. See also H. Chambert-Loir's article in this volume.

22 F. Valentijn, Oud en Nieuw Oost-Indiên, vol. 4, p. 233. 
Around 1591, according to the Wajo'chronicle, the "Old Prince" Karaéng Matoaya, then still young and not the ruler of Tallo' yet, but already the prime minister of Goa, visited the wise Arung Matoa La Mangkace' To Udama in order to conclude an alliance with Wajo'. And on that occasion, they had a discussion on how one should behave toward one's fellow men and toward God, which seems to reflect genuine religious preoccupations and may be a witness to the fact that both men had been influenced by foreign religious thinking and were in search of a new truth. ${ }^{23}$

In fact, around 1600, the Portuguese considered the Tallo' ruler as already won to Islam. ${ }^{24}$ However, at the same time, according to the Lontara' sukku'na Wajo', when the Malay community called the Three Dato' (again) to Makassar, they found it difficult to convert any of the Makassarese high nobility, upon which they chose to move to Luwu' ${ }^{25}$ According to oral Luwu' tradition, Islam was already known there: when Dato' Pattimang arrived in Bua (to the south of Palopo) he was welcomed by a nobleman called Tenriajéng, who was the first (local?) Muslim there, and that is why he is known also as I Assalang, from asal, origin. But he had kept his conversion secret, because nobody in the nobility could claim to have embraced Islam as long as the Luwu' ruler was not a Muslim himself, and that is why he was called also Tenripau, "Not-to-be-mentioned." A series of miraculous deeds convinced him that Khatib Sulaiman was really God's envoy, and he led him to the Datu in Pattimang (Malangkaé). After the latter's conversion, he became the Luwu' kadhi and that office remained in his family up to this century.

It may be in those first years of the 17th century that one Sayyid Jalaluddin al-' Aidid brought Islam to Cikoang, Laikang, and the Turatea area, south of Makassar. According to Cikoang sources, he was a son of Sayyid Muhammad Wahid, of Aceh, and Syarifah Halisyah. The latter's father, Sayyid 'Alawiyah Jalal ul-Alam was himself a son of one Sayyid Muhajirun al-Basrah. That "exile from Basrah" had fled Iraq at the beginning of the 16 th century because of political troubles (maybe the wars between the Ottoman empire and the Persian kingdom which erupted in 1514). From Aceh, Sayyid Jalaluddin went to Banjarmasin, where by the end of the 16th century he was delivering a teaching heavily tinged with Shi'ite influence. There, he converted a Makassar nobleman from Binamu, exiled in Banjarmasin for murder, and married his daughter. He then went to Goa, where he met some sort of opposition from the ruler, so that he moved to Cikoang, where he converted the still pagan nobility and population. ${ }^{26} \mathrm{His}$ arrival there is still commemorated every year at the occasion of the Maulid festival. ${ }^{27}$

From all this scattered information, one can reach two kinds of conclusions. First, it seems that the propagators of Islam in South Sulawesi were linked to a Champa-PataniAceh-Minangkabau-Banjarmasin-Demak-Giri-Ternate network. We have seen that in 1548, Demak was willing to Islamize Makassar. Well, it may not be by chance that about the same

23 J. Noorduyn, Een achttiende eeuwse kroniek van Wadjo': Buginese Historiography (The Hague, 1955), pp. $259-61$.

${ }^{24}$ M. Godinho de Eredia, "Report on the Golden Khersonese," trans. J.V. Mills, JMBRAS 7, 1 (1930): 245.

${ }^{25}$ The Lontara' Sukku'na Wajo' is a compilation made in Wajo' in the 18th century after the chronicles of the main South Sulawesi states. It was ordered from the Ranreng Bettempola (one of the three highest Wajo' officials), La Sangaji, by the Wajo' ruler (Arung Matoa), La Mappajung ( $\pm 1764-1767$ ). The copy I have used was handwritten by the last Ranreng Bettempola (d. 1970) Andi' Makkaraka. I am very grateful to the owner of the copy, Prof. Andi' Zainal Abidin Farid, for procuring me photocopies of the relevant pages.

${ }^{26}$ A. Makarausu Amansjah, "Mazhab Sji'ah di Tjikoang," Bingkisan Jajasan Sulawesi Selatan dan Tenggara 3, 1-2 (1969): 28-30.

27 See Gilbert Hamonic's article on the Cikoang Maulid in Archipel 29 (1985): 175-89. 
time the head of the Muslim community there was called nakhoda Bonang, when one remembers that the first imam of Demak was Sunan Bonang, one of the Nine Wali of Java. He was a son of Sunan Ngampel, another Wali, whose disciple and adoptive son was Sunan Giri, a third Wali. ${ }^{28}$ Now, in Giri, were trained Sultan Zainal Abidin, the first Muslim ruler of Ternate, ${ }^{29}$ and much later, if one is to believe local tradition, Dato' ri Bandang. ${ }^{30}$

Makassar sources say that among the Muslim community were not only people from Patani, Trengganu, Pahang, and Johor, but also from Champa. Now, some traditions say that Raden Rahmat (Sunan Ngampel) was a nephew of the Cham princess ${ }^{31}$ married to one of the last kings of Majapahit, whereas another one speaks of a daughter of the putri Campa called Raden Joko Krètèk, also styled Hadipati Makasar due to her marriage there. ${ }^{32}$

Banjarmasin also had links with Demak, which helped the kingdom of Nagara Daha, and introduced Islam there. ${ }^{33}$ We have seen that it was also a kind of relay between Makassar and Aceh. And Aceh itself, which is mentioned several times as the starting point of muballigh who came to South Sulawesi, ${ }^{34}$ exerted its influence on Minangkabau, where the three Dato' were to come from.

More research might help to enlighten links which, at the moment, are just conjectural, by looking for more evidence. The propagation of Islam in South Sulawesi would not appear to be a succession of isolated events any more, but can be seen as a part of an overall process.

But another remark seems to me more important: we have just seen that, prior to their official acceptance of Islam, the South Sulawesi people had been for more than 125 years exposed to regular contacts with Muslim traders and muballigh, familiarized with Islamic teachings, and had submitted to external pressures in favor of conversion, while managing to remain relatively unaffected by the new faith-although at some places there had been a number of Makassar and Bugis Muslims long before the official acceptance by the rulers. And then, within only seven years, everything changed. That fact has to be explained.

It is not enough to say, as did Noorduyn, that "conversion to Islam took so long because the deep changes it implied provoked strong resistance among a people keenly attached to its custom and proud of its own culture." 35 One has to understand how and why that resistance subsided. Did the people's attitude change, and how was that possible? Was Islam not seen as in conflict to their customs and culture any more? In brief, what happened which made those deep changes possible?

\footnotetext{
${ }^{28}$ H.J. de Graaf, Geschiedenis van Indonesië (The Hague, 1949), pp. 87-90; Pigeaud and de Graaf, Islamic States in Java, p. 7.

29 Sartono Kartodirdjo, Marwati Djooned Poesponegoro, and Nugroho Notosusanto, Sejarah Nasional Indonesia, vol. 3 ( Jakarta: Departemen Pendidikan dan Kebudayaan, 1975), p. 94.

$30 \mathrm{~J}$. Noorduyn, Een achttiende-euwse kroniek.

31 Pigeaud and de Graaf, Islamic States in Java, p. 5.

32 A. Zainal Abidin, "Siapakah Radèn Djoko Krètèk?" Bingkisan Jajasan Sulawesi Selatan dan Tenggara 1, 21 (1968): 7-20.

33 Sartono Kartodirdjo et al., Sejarah Nasional Indonesia, vol 3, p. 97.

34 Ibid., p. 34. According to Drs. Abu Hamid, the Three Dato' themselves, although they were born in Minangkabau, had acquired their religious knowledge in an Acehnese zawiyah. And indeed, at that time, Aceh was an important center of religious studies, which was not the case for Minangkabau.

35 Noorduyn, Een achttiende-eeuwse kroniek.
} 
In order to answer, one has to try and discover more about the exact motives of that early resistance to Islam-the more so as we know that at the same time as South Sulawesi rulers resisted Islamization, some of them were showing signs of deep interest in Christianity.

There is a very well-known story, told by such people as Tavernier ${ }^{36}$ and Gervaise, ${ }^{37}$ about how, in his hesitation between both religions, "the king of Makassar" resorted to chance. At the same time, he asked for priests from Portuguese Malaka and for ulama from Aceh (Gervaise) or Mekkah (Tavernier), taking an oath that he would embrace the religion of the first who arrived. As the governor in Malaka neglected his duties as a Christian, the Muslims arrived first, and won. That story could well have developed from information given around 1630 by Barreto de Resende, ${ }^{38}$ saying that the king had asked for a priest from Malaka to teach him the Christian faith, but that there was much delay, so that a "Moor" called "Lucar," having come first, succeeded in winning him to Islam. And indeed, around 1620, Karaéng Matoaya told Father Luis de Andrade that he had repeatedly asked for Catholic missionaries without any results, and that he had eventually become a Muslim at the instigation of the Sultan of Johor. ${ }^{39}$

\section{Between Christianity and Islam}

It is now a well-established fact that in 1544, two South Sulawesi rulers, those of Suppa' and Siang respectively, took the opportunity of the visit of a Portuguese trading ship to ask baptism from its captain, Antonio de Paiva, for them and a number of their followers. The following year, another expedition was sent to South Sulawesi, with a priest, Father Vicente Viegas, on board. The new rulers of Bacukiki' and Alitta and their retainers were baptized too. That same year, 1545, Father Viegas went to Tallo', where, according to a Portuguese source, he baptized the ruler. It must have been I Mappatangkangtana Daéng Padulung, known after his death as Tuménanga ri Makkoayang (about 1545-1577), a man who was to play an important role in Makassar history. ${ }^{40}$

After these auspicious beginnings, the relationship between Portuguese Malaka and South Sulawesi was, however, interrupted for fourteen years because of an unfortunate incident (a Portuguese officer had abducted a Suppa' princess). When regular relations were resumed, the baptized rulers of Suppa', Bacukiki, and Alitta were dead and their lands had lost their independance to the increasingly powerful Goa. What the attitude of Tuménanga ri Makkoayang - then the Makassar strongman-at the same time ruler of Tallo' and prime minister of Goa-was toward Christianity is not precisely known, but in several letters written by Portuguese he is still referred to as a Christian-although probably a nominal one. However, one repeatedly reads of local Christians asking in vain for priests to be sent to instruct them. ${ }^{41}$ Strangely enough. for many years, no one volunteered for that mission.

36 J.B. Tavernier, Les six voyages de ... en Turquie, en Perse et aux Indes . . ., vol. 3 (Paris, 1679), pp. 443-44.

${ }^{37}$ N. Gervaise, Description historique du royaume de Macaçar (Paris, 1688), pp. 161-64.

38 Barreto de Resende, "Account of Malacca," trans. G. Maxwell, JSBRAS 60 (1911): 4.

${ }^{39}$ C. Wessels, "De katholieke missie in Zuid-Celebes, 1525-1668," Het Missiewerk, 28, 1 (1949): 130.

${ }^{40}$ See my article "Les premières données occidentales concernant Cèlèbes-Sud," BKI 133, 2-3 (1977): 255. The Lontara' Sukku'na Wajo' acknowledges the conversion to the Christian religion (agama keriseténg sarani or agama Yésuite) of the rulers in Suppa', Bacukiki', and Siang, and the inclination of the Makassar people in Goa for that religion (p. 230).

41 A. Basilio de Sá, Documentaçâo para a história das Missôes do Padroada Português do Oriente; Insulindia (Lisbon), vol. 2 (1550-1562), 1955, p. 348; vol. 3 (1563-1567), 1956, p. 103. 
Even more strange, not much is known either from Portuguese or local sources about the four young princes sent in 1545, to the Jesuit college in Indian Goa. According to the Lontara' sukku'na Wajo', two of them were of the Goa (Makassar) nobility, and Professor Andi Zainal Abidin Farid thinks that they were Tumapa'risi' kallonna's (dead about 1547) sons. We know also through Portuguese sources that in 1560 only one of them was still at the college. ${ }^{42}$

At least, at some time between 1580 and 1590, four Franciscans were sent to South Sulawesi. ${ }^{43}$ It could have been the beginning of a prosperous mission, but their stay was short lived, for reasons which will be discussed later. No further attempt was made to Christianize those people although, from that time on, many Portuguese settled in Makassar, where they constituted an important community, which at times numbered about 500 residents. ${ }^{44}$ Eventually, two other Franciscans did come, but this was in 1610, when the "Islamic wars" were nearly over, and they could just take care of the Portuguese and mestizo Christians.

Still, strangely again, although they had become devout Muslims, the Makassar rulers continued to show more than benevolence toward Christians and, especially, the Catholic faith.

For instance, in 1614, Sultan Ala'uddin wrote to Manila to invite the Franciscans there to establish a house in Makassar. ${ }^{45}$ Again, in 1621, a Spanish report tells us that "the king has sent to the Governor of Ternate to seek clerica," and that two Jesuits and two Dominicans had been there recently from the Philippines. ${ }^{46}$ At one time, there were in Makassar three churches and 3,000 Christians, including local ones, some of them even related to Makassar princely families: Francisco Mendes, the secretary of Sultan Hasanuddin for Portuguese affairs, was probably a son of Sultan Malikussaid by a Portuguese wife. ${ }^{47}$

Moreover, reports written by successive clerical visitors to Makassar, such as Father Luis de Andrade in 1625,48 Sebastian Manrique in 1643,49 Jacques Maracci in 1651,50 Alexandre de Rhodes in 1653,51 Domingo de Navarrete in 1657,52 Joseph Tissanier in 1663,53 all show that Karaéng Matoaya, his son Karaéng Pattingalloang, and his grandson Karaéng Karunrung always manifested an outward sympathy to Catholicism. Karaéng Pattingalloang had

42 J. Wicki, Documenta Indica, vol. 4, (1557-1561), 1956, p. 838. The Lontara' Sukku'na Wajo' just says that these two Christian princes came back to Goa, and that they were responsible for the calling of Portuguese priests.

${ }^{43}$ P. de Trindade, Conquista espiritual do Oriente (Lisbon, 1967), vol. 3, p. 492-93.

44 B. Schrieke, Indonesian Sociological Studies, 2 vols. (The Hague and Bandung, 1955): 1, 69.

45 A. Reid, "A Great Seventeenth Century Indonesian Family: Matoaya and Pattingalloang of Makasar," Masyarakat Indonesia 3,1(1981).

$46 \mathrm{H}$. de los Rios Coronel, Memorial y relacion parc Su Magestad del procurador General de las Filipinas, (Madrid, 1621), in Blair and Robertson, The Philippine Islands (1493-1898) (Cleveland [Ohio], 1903), vol. 19, pp. 262-89.

47 C.R. Boxer, Francisco Vieira de Figueiredo: A Portuguese Merchant-Adventurer in Southeast Asia, 1624-1667, Verhandelingen KITLV (52) (The Hague, 1967), p. 17.

48 Wessels, "De katholieke missie."

49 S. Manrique, Travels of Fray Sebastiën Manrique, 1629-1643, trans. C. Eckford Luard (Oxford, 1927), vol. 2, pp. 79-81.

$50 \mathrm{~J}$. Maracci, Relation de ce qui s'est passé dans les Indes orientales ... (Paris, 1651), pp. 75-77.

51 A. de Rhodes, Divers voyages du Père Alexandre de Rhodes en la Chine et d'autres royaumes de l'Orient (Paris, 1653), p. 279.

52 D. Navarrete, The Travels and Controversies of Friar Domingo Navarrete, 1618-1686 ed. J.S. Cummins (Cambridge, 1962), pp. 114-16.

53 J. Tissanier, Relation du voyage depuis la France jusqu'au royaume de Tunquin (Paris, 1663). 
a deep knowledge of the works of contemporary Catholic theologians and even used to participate in church services or processions.

Thus one is left with more questions: if the South Sulawesi people had resisted so long before accepting Islam because it implied "deep cultural changes," why is it that they were so much attracted by Christianity, conversion to which implied no less deep cultural changes? But also, why were their reiterated demands for priests so inadequately answered by the Portuguese? Why was the Franciscan mission so short lived? And what happened, finally, which changed everything almost instantly, in such a way that South Sulawesi, still almost completely pagan in 1605 and sympathetic towards Catholicism, had turned completely Muslim in 1611?

My working hypothesis is that, when first acquainted with Islam, South Sulawesi rulers found in its teachings certain aspects which they feared would jeopardize social order and threaten their power; so that, although it was clearly in their interest in terms of both foreign policy and trade to adhere to the same religion as their main partners in the Archipelago, they delayed their conversion for more than a century. Now, in their eyes, Christianity, and especially Catholicism, was different in that respect, and would have made a very convenient state religion. Their religious sympathy was on a par with their sympathy for the Portuguese as their favorite Western trading partners, and later as their best allies against Dutch enterprises.

In fact, their sympathy for Catholicism may have rested on some misunderstandings, and this is probably what caused the Franciscans to interrupt their mission. Not hindered by Christian competition any more, Islam now had full scope for winning the contest. The main role of the Three Dato' must have been to contrive a way of solving the apparent incompatibility betwen Islam and traditional order. That obstacle put aside, conversion could take place in a very short time.

According to that working hypothesis, the main point of incompatibility was the myth of the divine descent of the nobility through the manurung, white blooded people descended from heaven, which all local dynasties (be they Makassar, Bugis. Mandar, or Toraja) claim as their founders. That myth was narrowly linked to theological views in which a unique Deus otiosus (in Bugis: Déwata Séuwaé) had generated a primordial, divine couple, who in turn, had begotten a number of gods-dewata-from whom the manurung originated. Ordinary mankind descended only from the latters' servants and slaves. From the beginning, political roles were thus distributed. Clearly, such a myth could not be shaken without putting traditional social order in danger. If the first, mostly Malay, Muslim settlers, when preaching their faith, insisted on tauhid, stressing the uniqueness of God and the fact that He was not begotten and does not beget; ${ }^{54}$ and if, being traders, not noblemen, they claimed, as Islam teaches, that all men, being all Adam's offspring, are equal-then one can understand the reluctance shown by local rulers toward that religion. It is enough to know how strong the belief in manurung and in the heavenly origin of the nobility still is in present day South Sulawesi, after nearly four centuries of acceptance of Islam, and how much traditional social and political structures depended on it, to guess what opposition Muslim propaganda may have met at first.

Conversely, after the establishment of the Portuguese in Malaka, people could have gathered information about Catholic teachings, perhaps through polemic arguments forwarded by the Muslims themselves, which may have appeared as contrasting strongly with

${ }^{54}$ See Surat al-tawhid of the Qur'an, and particularly CXII, 3. 
Islamic tauhid, such as, for instance, the dogma of the Trinity, calling Christ the "son of God," and the Virgin Mary the "Mother of God," the worship of saints, etc. This could have given the South Sulawesi rulers the impression that, by adhering to such a religion, they would be able to maintain their political myths and keep at least part of their original creeds. Moreover, the Portuguese would become their allies.

In that respect, it is significant that, during the visit that Karaéng Matoaya paid again to the old Arung Matoa Wajo' ToUdama in 1607, shortly before the latter's death, and although the Karaéng was already converted to Islam, the questions he asked of him were "Is God one or many? Can God have a father and a mother? Can He beget children?" 55

In 1544 the questions the rulers of Suppa' and Siang asked Antonio de Paiva before accepting baptism, concerned inter alia the worshipping of saints, and especially of St. James, the patron saint of Iberian countries, whom South Sulawesi peoples may have compared with the semi-divine founders and protectors of their local kingdoms. Other questions then debated were about the reasons for hostility between Portuguese and Muslims, and of course about God, creator of everything; about Christ, the Son of God, and how after His ascension to Heaven, He had sent His Apostles to bring forth His word to all men; and about God's commandments. All these points must have been raised in answer to precise preoccupations of the two rulers, who then debated them again with their families and retainers. ${ }^{56}$ What is clear is that, despite fierce opposition from Muslim settlers, and strong objections from the bissu clergy, they decided to become Christian.

However, the bissu were to remain a ticklish point in case of change to any religion, be it Christianity or Islam. Their incompatibility with the latter was evident for a number of reasons, and not only because of their transvestism. The main reason was rather that they were priests and that they specialized in elaborate rites, centered on offerings to spiritual beings, whereas Islam knows no clergy, and has simple rites, centered on prayer, which is directed toward the Only God.

With Christianity, differences were less conspicuous. The Portuguese had correctly identified them as the rulers' priests (os podres destes reis); ${ }^{57}$ conversely, South Sulawesi people may have identified Catholic priests with a kind of bissu, since they too conducted intricate ceremonies with offerings (at Mass) and processions, where, as the bissu, they acted as intermediaries between heaven and Man; and as the bissu, they wore different garments from other men's and had no commerce with women.

Particularly interesting in that respect is that the reason given by the four Franciscans for not having carried on their mission in Makassar in the 1580 s is that "they were assumed to be homosexuals and thus became the object of unwelcome attention." 58 That confusion cannot have been produced just by the fact that "they were clean-shaven and did not carry krisses," since most Makassar men depilated their (scarce) beards and not all of them wore krisses. In any case, it was easy for the Franciscans to grow beards and have a weapon on them. My impression is that they soon discovered that those measures were not enough, and that, considered as Portuguese bissu, they were assumed, not only to indulge in the "hateful sin," but also to play the same role as they did as the specialists in princely rituals and as guaranteeing the semi-divine status of the nobility. It must have very soon been

\footnotetext{
55 Noorduyn, Een achttiende eeuwse kroniek, p. 263.

56 Jacobs, "The First Locally Demonstrable Christianity in Celebes," p. 295.

57 Ibid., p. 301.

58 de Trindade, Conquista espiritual do Oriente.
} 
obvious to them that much of the sympathy professed by South Sulawesi rulers toward Christianity had rested on deep misunderstandings of the Catholic faith, and equally obvious to the rulers that no compromise could permit them to maintain their bissu along with the Catholic clergy, and that Catholic dogma was no more reconcilable with the manurung myth than Islam.

\section{Acceptance of Islam}

At that point, Christianity and Islam could be considered, from a religious point of view, in a similar situation. But from an economic and strategic point of view, Islam was in a better posture, since most of the trading partners of the South Sulawesi people were Muslims, and already a number of Muslim communities, including foreign traders and probably also local converts, were established in several parts of the land. Moreover there were Muslim pressures in favor of conversion, whereas the Catholics, on the contrary, did not seem to be willing to respond to overtures. So, already around 1600, the Portuguese believed that Christianity had lost the religious competition, and considered Karaéng Matoaya already a Muslim, although he had not yet taken any decisive step.

The importance given by local tradition to the Three Dato' leads me to think that they were the ones who found out how to overcome the hesitations of Karaéng Matoaya and his fellow rulers - probably at the initiative of one of them, namely Dato' ri Pattimang.

We have seen already that, probably around 1576, Dato' ri Bandang had tried to propagate Islam in Makassar, to no avail. At the beginning of the 16th century, he came back with two more companions, known later as Dato' ri Pattimang and Dato' ri Tiro. There, they again met (the probably usual) difficulties. At that point, they decided to go to Luwu', for, "if power was in Goa, excellence was in Luwii"" (ri Luwu'alebbirenna, ri Goa awatanna). ${ }^{59}$

If my hypothesis is correct, that move was not intended only to convert the Luwu' ruler because of his remaining prestige but, more essentially, because Luwu, as the cradle of South Sulawesi nobility, and the central place in the myth of origin, was felt as the key strategic point, the conquest of which would open the whole of South Sulawesi to Islam. ${ }^{60}$ For there, according to La Galigo, Batara Guru, the eldest son of the main god of Heaven, was believed to have set foot on earth, until then still unpopulated, to create the first human kingdom; there his first born infant had died and changed itself into rice; there, his grandson Sawerigading, the cultural hero of the Bugis, considered by some as the ancestor of all manurung in South Sulawesi, had lived his childlhood, and there he had come back at the end of his earthly life before being swallowed up by the waters of the gulf and becoming the new ruler in the Underworld; there, also had the bisu rites been celebrated for the first time on earth.

According to local traditions, Dato' Pattimang, who was to spend, from then on, most of his life in Luwu', centered his teaching on tauhid, not in the usual Muslim way but by using Bugis beliefs about the One God (Dewata Séuwaé) and about Sawérigading. No text, to my knowledge, permits us to know what his teachings were exactly, but I suspect that many stories found in lontora' (manuscripts) concerning the Creation, giving Adam and Eve as the parents of the former Bugis gods, or showing Sawerigading as a kind of prophet avant la

\footnotetext{
${ }^{59}$ Mattulada, Islam di Sulawesi Selatan, p. 20. According to the Lontara' Sukku'na Wajo' (p. 240) they took that decision after consultation with the local Malay community.

${ }^{60}$ The answer of the Malays had been "Malebbi'-é Datu-é ri Luwu', nasaba' ku maneng-i poléang-poléangenna arung$e^{\prime \prime \prime}=$ "the most exalted is the king of Luwu', because it is from there that all the (local) lords have their origin."
} 
lettre who, before his descent to the Underworld, announced the coming of Islam, etc., may at least represent some of their off-shoots. ${ }^{61}$ The only place where Dato' ri Pattimang traveled once in Luwu' was Wajo' ${ }^{\prime 2}$ this is probably not by chance, since after Luwu', most of the La Galigo episodes are located there. Until now, it has remained the place where the hierarchical system is the strongest and where the La Galigo is most widely known.

From Luwu', Dato' ri Pattimang's younger brother, known as Dato' ri Tiro, went to the konjo-speaking area near Bira, which was, in some respects, for the Makassar people much the same as Luwu' was to the Bugis people. There, until now, the patuntung community, and especially the Amma Toa ("Old Father"), the spiritual leader in Kajang, bear witness of an ancient system of beliefs strongly marked by mysticism. ${ }^{63}$ No wonder that Dato' ri Tiro chose to center his teachings on tasawuf. According to Mattulada, he might have been influenced by the (somewhat heretical) thought of Hamzah Fansuri. Research on the spot might provide more insights on his doctrine. ${ }^{64}$

As for the third Dato', Dato' ri Bandang, he left Luwu' for Goa/Tallo' and he was the one who succeeded in converting Karaéng Matoaya. One cannot help being struck by the rapidity of his conversion, since he uttered the syahadat only eight months after the Datu of Luwu'. One legendary story relates that when Dato' ri Bandang landed, Karaéng Matoaya went to meet him and greeted him with the Muslim salutation Assalamu alaikum warrahmatullahi wabarakatu, and that he pronounced the syahadat on that same day. ${ }^{65} \mathrm{It}$ is generally understood by the people as a miraculous event, since they assume that Karaéng Matoaya knew nothing of Islam before. Of course, he was probably well instructed in that religion, and one can interpret the story as showing that he was awaiting the Dato', ready for conversion insofar as prior obstacles would have been removed. And that was what the three Dato' had just done in Luwu' ${ }^{\prime} 66$

61 Such texts are exemplified in G. Hamonic, "Pour une étude comparée des cosmogonies de Célèbes-Sud. A propos d'un manuscrit inédit sur l'origine des dieux bugis," Archipel 25 (1983): 35-62, and Ch. Pelras, "Le panthéon des anciens bugis vu à travers les textes de La Galigo," ibid., pp. 63-96.

62 Mattulada, Islam di Sulawesi Selatan, p. 42. On hierarchy in Wajo", see my article "Hiérarchie et pouvoir traditionnels en pays Wadjo'," Archipel 1 (1971): 161-91 and Archipel 2 (1971): 197-223.

63 Mattulada, Islam di Sulawesi Selatan, p. 30; on Kajang and the Amma Toa, see K.M.A. Usop, Pasang ri Kajang : kajian sistim nilai di "Benteng Hitam" Amma Toa" (Ujung Pandang: PLPIIS, 1978). According to the Lontara' Sukku'na Wajo', "Katté' Bungsu maélo' palebbang-i mappaguruang-i paddisseng ngeng tasaupu' (hakiki), nasaba' naseng-i magampang ttama ri akkalenna taué nalolongeng ana'guru. . . . Na péné maraja-na assisalanna, naléppangna Katté" Bungsu ri Kajang ri wanua ri Tiro, na ku-na nappaguru, mébbu' to-ni masigi' ri wiring salo 'é, na-ko to-na maté nariaseng-na Dato' ri Tiro" "Khatib Bungsu wanted to preach Islam through the teaching of mystical knowledge, which he thought easier to accept to those who had become his disciples. . . . And as their disagreement was increasing more and more, he stopped in Kajang, in the village of Tiro, and there he delivered his teaching, and he built also a mosque near the river. And there also he died, so that he was called the Dato' from Tiro" (p. 241). 64 According to Drs. Abu Hamid, Dato' Tiro's teachings can be found in a manuscript which is still kept in Bira. 65 Mattulada, Islam di Sulawesi Selatan, p. 11. Other versions are that summarized by Henry Chambert-Loir in this same issue and that of the Lontara' Sukku 'na Wajo' which runs as follows: after having established himself in Kaluku Bodoa, Abdul Makmur had the habit of visiting regularly Karaéng Matoaya in Tallo's fort (bénténg), looking for a way to win him to Islam. One night, Karaéng Matoaya dreamt that he met the Prophet at the gate of the fort, and that the latter spat in his mouth, thus giving him religious knowledge; whatever question would be asked him by Dato' Bandang, he would know the answer. In the morning, Karaéng Matoaya went to the place he had seen in his sleep, and there he discovered the Prophet's footprint printed in a stone. Convinced of the truth of his dream, he went to Dato' Bandang's palace, and expressed to him his will to become a Muslim (p. 241).

66 Noorduyn, "De islamisering van Makassar." The story is also told in the Lontara' Sukku'na Wajo'. 
However, not everybody was ready for conversion. Enough has survived in local traditions to assume that there was some fierce opposition from two categories of persons. Among them must have been a number of bissu, since some of them were forced into exile in Kaili. The others were part of the nobility, among whom one of Karaéng Matoaya's sons, who tried to take up arms against his father, whereas a brother of the ruler of Goa, by name I Mangnginyarrang Daéng Makkiyo Karaéng Kanjilo Tumamaliang ri Timoro', resorted to "humiliation." 67 We learn the nature of the humiliation from Tavernier's and Gervaise's accounts: when the first royal mosque was built (probably that in Kaluku Bodoa) and on the eve of the first Friday public prayer, that prince introduced pigs into the building, slaughtered them, and smeared the walls and the pulpit with their blood, ${ }^{68}$ thus derisively desacralizing it, probably by the very rites used in pagan South Sulawesi to consecrate a newly built house!

That incident (if it is true) and other acts of opposition may have been the cause of the twenty-six months' delay between the date of the official conversion of the Tallo' ruler and the first public prayer of the people of Tallo' and Goa in the rebuilt royal mosque. It was during that time, not long before that momentous event, that Karaéng Matoaya paid his last visit to ToUdama in Wajo', to ask him questions about God, an indication that, even then, there must still have been much debate in Makassar. But after November 9, 1678 the page was definitively turned.

\section{The Long Struggle for Islamization}

Local traditions say that Dato' ri Bandang had first concentrated his efforts on building the sara' (sy'ariat) putting the main stress on the religious obligation of the "five pillars," on the correct celebration of rites such as circumcisions, marriages, and funerals according to Islamic rules, and the development of religious teaching. As for prohibitions, those concerning the consuming of pork and adultery were among the most strongly enforced. Other forbidden actions, such as consuming alchohol and opium, lending money with interest, gambling, and even bringing offerings to sacred places or worshipping the regalia, although getting lip-condemnation, do not seem to have been very energetically fought at the beginning.

Around 1630, the organizational aspects of the syariat began to be implemented in all of the South Sulawesi kingdoms, and it appears that the nobility, now that it had chosen to side with Islam, endeavored to monopolize all the important positions.

At the beginning, there was only one mosque in each kngdom or petty kingdom. All offices, such as imam, khatib, bilal, kadhi, were handed over to people of high nobility. Those people, called paréwa sara' (the instruments of the syariat) in Bugis and in Makassar as well, were put on an equal footing with the former customary officials (parétwa ade'), and were equally members of the ruler's council. The syariat itself became incorporated in the body oi customs called pangaderreng in Bugis and pangadakkang in Makassar. ${ }^{69}$ For instance, Islamic funerals completely replaced traditional funerals, although some elements of the former rituals were maintained in the funerals of the highest nobility; the reading of the Qur'an and of the kitab Barazanji on Friday's eve or on the occasion of domestic rites tended to replace, but never to put completely aside, the reading of the La Galigo epic. In other cases, Islamic

67 Information received from Prof. Andi' Zainal Abidin.

68 Tavernier, Les six voyages, p. 444, and Gervaise, Description historique, pp. 164-66.

${ }^{69}$ About all that process, see Mattulada, Islam di Sulawesi Selatan. 
practices were combined with traditional ones; for instance, the Islamic ceremony of hakikah performed for newly born children was combined with the traditional ceremonies of putting the child in his cradle for the first time (mappénré ri tojang) and of the purification of the young mother (makkuwaé lawi'); and the traditional tooth-filing ceremony was often combined with Islamic circumcision, which, besides, replaced traditional subincision but preserved elements of the former ceremony. Sometimes, again, an Islamic part was just added to an otherwise almost completely traditional ceremony, as for instance in weddings, where the Islamic akad nikah was just introduced in the sequence of rites without much modification of the rest.

Such a mixture of heteregoneous elements may not be just a mark of the propensity of South Sulawesi people, like other Indonesian people, toward spontaneous syncretism. It may be, on the contrary, the result of a conscious policy of the first propagators of Islam, not much different from that adopted in pagan Europe by the first Christian missionaries: given the impossibility that the people, and especially the nobility, would abandon immediately those elements of the former tradition which they considered essential to their culture, and maybe for fear of losing the contest to the Portuguese Christians, the Dato' may have chosen to come to terms with those elements, probably hoping that religious teaching and daqwah would in the long run bring them into disuse. To them, conversion must have been the main goal to achieve first; then real Islamization would be able to begin.

Conversely, the nobility, conscious of their inability to oppose any longer the rise of Islam in South Sulawesi, at least among the most progressive and economically well-to-do people, and anxious to maintain and even improve their position in society, had tried to combine the advantages of both systems, by monopolizing Islamic offices on the one hand, and on the other hand by maintaining those elements of the former system on which their political power had rested. Most of them must have seen that equilibrium as ideal, and have been hoping to carry on the status quo for ever. But, with such a contentious situation at the start, the equilibrium could not be maintalned for long, and sooner or later the opposing forces were to bring forth the dynamics of evolution.

\section{Through Tensions Toward Evolution}

The description given in 1688 by Nicolas Gervaise of Makassar of religious life shows that in less than three generations after official conversion, Islam had already become an essential part of South Sulawesi culture.

Particularly noteworthy in his description is the important role played by religious masters called by him aguy, i.e. haji, who seem to have been hierarchically dependent on higher masters called by him Touan (Tuanta is actually a term used by the Makassarese toward renowned ulama). His mention that that title was awarded in Mekkah by high authorities seems to indicate some acknowledgement of the teaching role performed by the syaikh of some mystic order, the more so as the places where those Touan were teaching their (male and female) santari (students) look in Gervaise's description, not just like present-day pesantren, but much more like some kind oI zawiya (monastery).70

As a matter of fact, it is well known that, already in the second half of the 17th century, mystic orders had made their way into South Sulawesi. One of the key actors in that penetration was the celebrated Syeikh Yusuf, known by the Makassarese as Tuanta Salamaka (Our

${ }^{70}$ Gervaise, Description historique, pp. 82 and 194-201. 
Gracious Master). Probably a (lower?) relative of the princely Goa family, ${ }^{71}$ he had left Makassar for Mekkah in 1645, at the age of 19. He is said to have stopped on his way in Aceh to follow the teaching of Nuruddin ar-Raniri, and then in Yemen, where he studied with two other mystic masters. After some time spent in Mekkah with another two other Sufi masters, he went to Damascus where he became initiated in the Khalwatiyah order and therefore received his title of Taju'1-Khalwati. ${ }^{72}$ Makassar tradition says that on his return from the Holy Land, around 1678, Syeikh Yusuf was much shocked by the state of syariat in South Sulawesi, and tried to purify religion there from pagan remnants and improper behavior. Those attempts, so the story runs, were strongly opposed by the nobility who were not prepared to have an end put to gambling, palm-wine drinking, opium smoking or bringing offerings to sacred places or objects. One must be careful to recognize that those are not just examples of un-Islamic behavior, but that through them more was at stake. Gambling had not only been a favorite pastime of the nobility since time immemorial (cockfights are a prominent feature in the La Galigo epos); it had, and still has among the Toraja, a ritual significance, being usually held on the occasion of communal festivals, such as harvest festivals, and at princely weddings; it was also a source of income for the rulers, as was the opium trade. Opium smoking and palm-wine drinking were not just addictions, but were indulged in by warriors before going to fight. Bringing offerings was not only a superstitious habit, but was thought of as the means to insure prosperity for the community, and in the case of arajang, or sacred places commemorating the ancestors of local dynasties, established the link between present-day rulers and their semi-divine forebears. In short, the nobility, by refusing changes on those particular points, showed that they were still holding tightly to the compromise put into being when Islam had become the state religion. Clearly, they were not prepared yet to accept an evolution which would endanger social order as they understood it. As a consequence, Syeikh Yusuf, who could not accept that compromise, left Makassar and settled in Banten where, as is well known, he married one of the Sultan's daughters. Later, he took an active part in the resistance to the Dutch, was caught by them, and was exiled, first to Ceylon and then to South Africa where he died in 1699.

All South Sulawesi nobility was not unanimous in supporting the above compromise; a few were in favor of a more Islamic way of life. That is well exemplified by the case of La Maddaremmeng, Sultan of Boné from 1631 to 1644, who had decided to apply the syariat literally, forbidding all superstitious practices, discarding the bissu, and liberating the slaves. Those measures had stirred up huge discontent in his kingdom and provoked an uprising led by the ruler's own mother, who sought protection and support in the Goa court. The result had been a war between Boné and Goa which in 1644 made the ruler prisoner and established direct rule on Boné. Those events were to have far-reaching consequences on the destiny of South Sulawesi, since it was in order to liberate Boné from Goanese oppression that the famous Arung Palakka allied himself with the Dutch, contributing to the fall of Makassar into their hands and to their establishment there as a colonial power after the Bonagaya treaty (1667).

The future Syeikh Yusuf had left South Sulawesi just at the end of the Goa-Bone war, at a time when the supporters of an Islam "adapted" to local conditions were triumphing; he

\footnotetext{
71 There are conflicting stories about his birth. Some say he was the son of a Shyeikh Khaidir from Binamu; some see in this Khaidir an incarnation of $\mathrm{Nabi}$ Khidir. And a tradition kept in some aristocratic families which claim descent from him says he was in fact born of a secret marriage of Sultan Malikussaid (and thus Sultan Hasanuddin's half brother) and that Syeikh Khaidir was only his adoptive father.

72 Mattulada, Islam di Sulawesi Selatan, pp. 37-38. More will be known about Syeikh Yusuf after publication of Abu Hamid's dissertation on him, including the translation of five of his books.
} 
had come back and gone again when he had seen the same prevailing attitudes. However, the seeds of a more radical Islam had been sown, and were beginning to grow. Syeikh Yusuf himself contributed to its development by his teachings and written works, which were disseminated by one of his sons and three disciples, the most famous among whom was the Bugis (from Rappang) Abdul Basir Adlarir al-Rafani, known locally as Tuan Rappang.

Their main efforts appear to have been directed against what seemed to be the main stumbling-block, that is to say, the nobility. It was among them primarily that Yusuf's disciples chose to implant the Khalwatiyah mystic order, and, it appears, not without success. It may have seemed to them another means, more congruent with true Islam, to assert their preeminence in society.

Such had been Syeikh Yusuf's indirect influence that after his death in South Africa, Sultan Abdul Jalil of Goa insisted on having his mortal remains brought back to Makassar, which was granted by the Dutch in 1705 . His grave in Lakiung is now one of the most visited places of pilgrimage in South Sulawesi.

In the long struggle for Islamization, a new phase had thus been initiated, where the South Sulawesi nobility, or at least part of it, played a new role: it can best be seen in such literary works (probably written in the 18th century) as the "Book of Budi Istirahat Indra Bustanil Arifin," a book of Islamic Malayo-Indo-Persian inspiration, very akin to, if not literally adapted from, the Mahkota segala raja or Taju's-Salatin, written in 1603 in Aceh by Syeikh Bukhari of Johor. That text, and others, might be seen as attempts to replace the pagan bases on which aristocratic power had rested until then (and especially the myth of the heavenly descent of the rulers) by an Islamic based ideology, where the rulers appeared as the representatives and instruments of Allah on earth. That ideology, new to South Sulawesi, was not new in the Malay world; indeed, the medieval Islamic, Persian-influenced idea of a kingdom centered on a ruler considered as the "Shadow of God" had been the basis of, among others, those Malay sultanates which South Sulawesi aristocrats had been connected with for years. ${ }^{73}$

We must keep in mind that South Sulawesi, marked as it was by deeply rooted traditions, was nevertheless not isolated in its island world, but was also part of an intricate network of commercial, political, and intellectual relationships with other Muslim kingdoms all over the Archipelago, and that it had connections as well with other Asian countries, including Muslim countries in India and the Middle East, where some of its young men went to study, and where some ulama came from. So the movement of ideas in the rest of the Muslim world was not unknown, and eventually had its echoes here too.

For instance, in the first quarter of the 19th century not very long after the end (1818) of the first Wahabite "empire," an Arung Hatoa (ruler) of Wajo' called La Memmang ToAppamadeng (ruled between about 1821-1825) tried to enforce, under the influence of an ulama known as Syeikh Madina, a Wahabite-inspired kind of Islam in his kingdom: superstitious habits were fought, sacred places were destroyed, attempts were made to apply Islamic law literally (lapidation for adulterers, cutting off of hands for thieves, etc.) and to introduce Islamic customs (wearing of veils by women). ${ }^{74}$ Those attempts were short lived, but showed that, among the South Sulawesi nobility, a more radical form of Islam was making its way, little by little. Wajo' is, by the way, among other kingdoms in South Sulawesi, one where, paradoxically, the La Galigo lore has been the most cultivated, the preeminence of nobility

73 A.C. Milner, "Islam and Malay Kingship," Joumal of the Royal Asiatic Society, 1 (1981): 46-70.

74 Mattulada, Islam di Sulawesi Selatan, pp. 50-51. 
has been the most asserted, and, at the same time, a kind of political democracy has existed for centuries, the role of merchants has been the most important, and the progress of Islamic reformism has been the most rapid.

In fact, what the word of a ruler could not obtain, i.e. the implementation of an Islam cleansed of its South Sulawesi impurities, was to be achieved by commoners, little by little. And it is their emergence as protagonists of Islamization which marks the next phase of its history.

Much is still to be done to document it precisely. Local manuscript sources mostly originate from aristocratic circles; and Dutch archives may not be very rich in information on topics which were not central to their interests in the 19th century; but one might find more relevant data after the extension of their sway to all of Sulawesi in 1906.

The advancement of two markedly different Islamic movements can be taken as examples of a deepening Islamization among commoners.

One is the Khalwatiyah, not the branch brought in by Syeikh Yusuf's disciples, but another one called Sammaniyah, founded in Medina by a Syeikh Muhammad bin Abdul Karim as-Samman. It was then introduced in the 18th century from Arabia to Palembang by his disciple Abdussamad al-Palembani and brought to Sulawesi in the middle of the 19th century by a Syeikh Abdullah al-Muniz. ${ }^{75}$ There were among its first members a number of high aristocrats (two of the first adherents became later, respectively prime minister (until 1854) and ruler, from 1860 to 1871, of Bone (under the name of Sultan Ahmad); but that branch also developed very quickly among the commoners; and even if there have always been some noble people among its members, their position there is no different from that of other, ordinary members. The loss of their preeminence in that domain has also been marked by the near disappearance as a separate branch of Syeikh Yusuf's Khalwatiyah. ${ }^{76}$

The expansion of the new order has continued until now. In 1976, according to the Bureau of Religious Affairs in Ujung Pandang, 150,000 members were registered throughout the province, as compared to less than 10,000 in the Naqsybandiyah and less than 5,000 in the Qadiriyah, which are otherwise the strongest mystic orders elsewhere in Indonesia.77

In South Sulawesi, those orders bear witness to the development of a mysticism set on purely Islamic bases, as contrasted with a syncretist mysticism including many elements taken from the pre-Islamic local religious system, which may be much more diffused in the province, but remains unorganized, and is probably doomed to gradual weakening and eventual oblivion.

The second important movement corresponds to the emergence of a new, egalitarian brand of Islam-of course more in conformity with primitive Islamic teaching, according to which there should be in Islam no differences between ranks, races, or genders- expressed by the establishment of "reformist" organizations which at the same time advocated a return to the purity of the doctrine as it was preached by the Prophet and an open mindedness toward the challenges of modern life. It is probably not by mere chance that most of

\footnotetext{
75 Abu Hamid's forthcoming dissertation, pp. 32-33.

76 According to Drs Abu Hamid, there are at the moment in Maros two Khalwatiyah khalifah, one for each branch-the Khalwatiyah Yusuf and the Khalwatiyah Samman-who ignore each other. But the followers of the Khalwatiyah Yusuf are now very few. Maros became a center of Islamic, mostly mystical studies, from the time when the ruler of Boné La Maddaremmeng, a sufi himself, was exiled there after his defeat.

77 Mattulada, Islam di Sulawesi Selatan, p. 115.
} 
their promoters were not from the nobility, but commoners, mainly traders. The pioneer here was one Haji Abdullah bin Abdurrahman, from Maros. After having spent ten years in Mekkah, in 1917 he came back to Makassar, where he founded a madrasah in which the teaching was decidedly reformist. A conflict soon burst out between him and the kali (Kadhi) of Goa with regard to the correct way of performing the Friday public prayer (should regular lohor prayer be performed after Friday prayer or not), which he eventually won. In 1923, he founded an organization called As-Sirath al-Mustaqim, which, three years later, at the initiative of an Arab batik trader from Surabaya called Mansur al-Yamani, united with the national reformist movement Muhammadiyah (founded in 1912).78

The South Sulawesi branch of that organization grew rapidly, despite the declared opposition from many in the nobility, especially in the ruling families of Boné and Goa. However the local aristocracy did not present a unified front any more: among them, an important minority was already open to new ideas. That was especially true of Wajo', with the democratic trends of its traditional government, the role of its inhabitants, including the ruling elite, in trade overseas, and the entry there, already mentioned, of Wahabite ideas in the 19th century. It was in Wajo' that the first local branch of the Muhammadiyah outside of Makassar was opened in 1928, due to the active approval and help of one of the most eminent Bugis princesses, Andi' Ninnong, then in charge of the office of Ranreng Tuwa. In Wajo' also were held, in 1928 the first, and in 1941 the sixteenth South Sulawesi regional conference of the movement, which at the latter meeting could already boast of 7,000 members, 30,000 sympathizers, and 5,000 pupils, a fifth of which were in Wajo' alone. ${ }^{79}$

Indeed, one of the main efforts of the movement was directed toward the development of schools alongside madrasah and pesantren organized according to modern conditions.

Confronted with those developments, which were felt by more traditional circles as a menace against the social and religious status quo, some local ulama, encouraged by a part of the ruling aristocracy, created also teaching institutions following the same model of modernity, but still professing the established doctrine of the syafi' $i$ school, which has been the legal school followed in South Sulawesi since the introduction of Islam. One of the most important of those institutions was the Madrasatu'l-Arabiyah Islamiyah, founded in 1932 in Wajo' by Haji As'ad (locally known as Haji Sade'), and renamed As'adiyah after the death of its founder, a Mekkah born and trained ulama of Bugis descent. That institution now boasts more than 7,000 pupils. ${ }^{80}$

After the Second World War, several similar institutions were founded by Haji As'ad's disciples, the most prominent being the Daru'l-Daqwah wal Irsjad, founded by Haji Abdurrahman Ambo' Dalle', which has now around 1,200 schools all over South Sulawesi, as well as in Kalimantan and Sumatra, among the Bugis diaspora there.

Although the teaching given in those institutions is plainly orthodox and not reformist, their action has had the same consequences on local socio-religious structures as that of the Muhammadiyah, by strongly lessening the religious role of the ruling aristocracy and undermining the pre-Islamic bases on which its power was established. Through both Muhammadiyah and non-Muhammadiyah teaching institutions, a new elite was shaped, of which only a minority came from the nobility, and many more from urban or wealthy rural

\footnotetext{
78 Ibid., pp. 55-56 and Abu Hamid's dissertation, pp. 54-55.

${ }^{79}$ H.S.D. Moentoe, Langkah dan oesaha kami tentang peringatan Conferentie Moehammadijah Daerah Selebes Selatan keXVI di Sengkang (Makassar: Labbakang, 1941).

${ }^{80}$ Mattulada, Islam di Sulawesi Selatan, pp. 62-64.
} 
commoners. That elite is constituting a significant proportion of the civil servants, teachers, entrepreneurs, and, of course, Islamic clerics (imam, khatib, teachers of religion, etc.) at work now, so that the influence of purified (be it reformist or orthodox) Islamic teaching is much more important than could be guessed from the given figures.

The same might be said of the Muhammadiyah, whose registered membership did not exceed 50,000 in 1975 (for a population of about 6 million); ${ }^{81}$ but their sympathizers are much more numerous and their influence is still stronger, due to the number of pupils in their schools, and to the key positions of many of their members at all levels of administration, teaching, and business.

The last fight for survival of the socio-religious order brought into being at the beginning of Islamization in South Sulawesi lasted from about 1945 to 1965.

At the outset of the Indonesian independence struggle, a clearcut cleavage could be seen between a large section of the nobility, leaning on a number of traditionnal ulama, still clutching to and defending the old system, on the one hand; and on the other hand, the partisans of a new religious and social order, many of whose leaders were former pupils of the Muhammadiyah schools or former members of the Muhammadiyah Hizbu'l-Wathan Boy Scout Association. Although both were in favor, mostly, of Indonesian independence, the former did not conceal their preference for the East Indonesia State (Negara Indonesia Timur), brought into being under Dutch influence in order to counterbalance the Nationalists and Unitarists of the Republik Indonesia. They probably saw there a chance to perpetuate or even revive their former status at the top of society, now that the old myths and rites on which it had formerly rested were dying, with political power on all South Sulawesi concentrated in the hands of a Conference of Rulers called Hadat Tinggi. Most of the officials of the syari'at (paréwa sara') were on their side. On the opposite side, independence fighters (pejoang) were not only struggling against the Dutch and for the establishment of a unitary Indonesian Republic; they also wanted to suppress what they branded as the "feudal" aspects of traditional society.

In the aftermath of the Revolusi, the disillusioned former partisans continued their fight as rebels (gerombolan), not only against the policy of the Central Government and what they considered as the denial of their rights, but also, still, against those "feudal" remnants, which they linked, not without good reason, with the perpetuation of superstitions, the continuation of bissu ceremonies, the visits to sacred places, etc.

It may be that, at the beginning, the rebellion had been caused by many other reasons; but the choice of the banner of Darul Islam by Kahar Muzakkar shows that his troops were really conscious of fighting a new musu'selleng for the completion of Islamization in South Sulawesi. ${ }^{82}$

\section{The Religious Situation in South Sulawesi: A Product of History}

This rapid survey of the history of Islamization in South Sulawesi is, I think, enough to enable the reader to understand how so many pre-Islamic and non-Islamic elements have managed to survive in the culture of the Bugis and Makassarese, two peoples who at the same time used to affirm their Islamic character. Indeed, the co-existence of such contradictory elements is not only to be found in one and the same culture, but even, often, in one

81 lbid., p. 115.

82 The best work on that period and on the Darul Islam movement in South Sulawesi is Barbara Harvey's dissertation, "Tradition, Islam and Rebellion: South Sulawesi 1950-1965" (Cornell University, 1974). 
and the same individual, such that the dichotomy of people into clear-cut groups, according to the model set up by Geertz for the Javanese of Mojokuto, and which some would like to use all over Muslim Indonesia, seems here inappropriate. One cannot group the Bugis or the Makassarese in really distinct santri or abangan categories, nor even see in their religious attitude a santri, an abangan, or a priyayi variant. Rather, one could distinguish a number of variables, which are not always linked to each other, such as: acceptance, partial acceptance, or refusal of Islam; the degrees of adherence to Bugis or Makassar pre-Islamic tradition (with its bissu and popular variants); the adherence to a Muslim tradition, be it the plain syafi' $i$ tradition or that of a particular tarékat, or the support of reformist ideas, and the degree of Islamic religious practice and observance of syari'at.

Islamization can thus be seen from an external point of view as a process acting on all of these variables, to achieve a full acceptance of Islam; a complete rejection of those Bugis or Makassar traditions which are not consistent with it; and a full observance of the syari'at. Further, from a reformist point of view, Islamization would also include those Muslim traditions which are not, to their eyes, in accordance with the pure, original, Islam, and are thus bid'ah (heresy). However, other Muslims would deny that.

On one end of the Islamization axis, one would thus find the less Islamized people, such as the members of the Tolotang community, and namely those called Tolotang Sammang-a Bugis community living mostly in and around Amparita in the Sidénréng kabupatén-who have refused Islam altogether and follow "Sawérigading's tradition." On the other end of that same axis, however, one could find different kinds of people, who would all be styled santri in Geertz's terms: religious masters in Islamic schools, ulama of the syafi' $i$ tradition, leaders of different tarékat, activists of the Muhammadiyah movement. Thus they do not form a homogeneous group, some people in that category even viewing the others as imperfect Muslims.

In between, the interplay of the above-mentioned variables would allow us to distinguish many different groups, which cannot be set on a continouous line. There are, for instance:

A few groups of Bugis and Makassar Christians, who have rejected both Islam and local religious traditions (a tiny minority indeed);

Other Tolotang, called Tolotang Bénténg who, having much in common with the other Tolotang, have however accepted part of the Muslim syari'at, and integrated some Muslim teachings in their tradition, so that they are sometimes called Tolotang Islam, although their adherence to pre-Islamic Bugis tradition is still strong;

The bissu, who, as priests of the former Bugis faith and practitioners of non-Islamic rites should logically be considered among the less Islamized people in South Sulawesi; however, most of them also acknowledge Islam as their religion, and some of them even went on the pilgrimage to Mekkah, so that there are now Haji bissu!

Conversely, many people who are zealous practitioners of Islam, who do their five prayers a day, are assiduous at the Friday congregation, fast scrupulously during Ramadhan, and manifest a real piety, at the same time participate in pre-Islamic rituals and believe in the reality of the déwata, as well as in the historicity of the myths. Besides, the coexistence of those heterogeneous traditions can take different forms. Some people could be called syncretists, insofar as elements of different traditions are, in their minds, integrated into one single system; others manifest a kind of split-personality, keeping two different and completely distinct systems, referring to one or the other according to circum- 
stances. Others, again, while adhering completely to orthodox Muslim ideas, at times behave in a way or follow practices foreign to Islamic tradition. And one could find other different examples.

All those contradictions, which look strange at first sight, are much easier to understand when referred to the historical process of Islamization in South Sulawesi. They manifest the interplay of two competing systems, one of which, Islam, used at the beginning elements of the other in order to be accepted, thus opening the path for a long-lasting struggle, the last phases of which we are now witnessing. 